\title{
HUBUNGAN PREEKLAMPSIA DAN PARITAS DENGAN KEJADIAN PARTUS PREMATURUS DI RSUD BANYUMAS PERIODE JANUARI SAMPAI DESEMBER 2017
}

\author{
Anissa Kusuma Dewi ${ }^{1}$, Andi Muh. Maulana ${ }^{1}$, Rizka Adi Nugraha Putra ${ }^{1}$ \\ ${ }^{1}$ Fakultas Kedokteran, Universitas Muhammadiyah Purwokerto \\ Email: annisakd71@gmail.com
}

\begin{abstract}
ABSTRAK
Latar Belakang: Preeklampsia adalah keadaan pada ibu hamil yang mengalami hipertensi dengan tekanan darah $\geq 140 / 90 \mathrm{mmHg}$ yang terjadi setelah umur kehamilan 20 minggu, dan disertai dengan proteinuria $\geq 300 \mathrm{mg} / 24$ jam. Setiap harinya di tahun 2015, 830 perempuan meninggal karena terjadi komplikasi kehamilan dan persalinan termasuk preeklampsia. Kesehatan ibu yang terganggu seperti preeklampsia akan mengakibatkan gangguan pada perkembangan janin. Salah satu gangguan perkembangan janin adalah preterm birth (kelahiran prematur). Kelahiran prematur yang dipengaruhi oleh preeklampsia atau eklampsia diakibatkan oleh terjadinya spasme pembuluh darah, apabila berlangsung lama akan mengganggu pertumbuhan janin serta meningkatkan tonus dan kepekaan uterus terhadap rangsangan sehingga menyebabkan partus prematurus. Bayi dengan kondisi prematur akan mengalami gangguan dalam kehidupan selanjutnya seperti asfiksia dan kematian neonatal.

Tujuan: Mengetahui hubungan antara preeklampsia dan paritas dengan kejadian partus prematurus.

Metode: Analitik observasional dengan rancangan cross-sectional. Sampel diambil dari data rekam medis pasien preeklampsia di RSUD Banyumas, periode Februari - Desember 2017. Data dianalisis menggunakan uji Chi-square. Hasil: Pasien dengan preeklampsia primipara dengan persalinan prematur sebanyak 4,83\%, pasien dengan preeklampsia multipara dengan persalinan prematur sebanyak 29,0\% dan uji Chi-square diperoleh nilai $\mathrm{p}=0,721$.

Kesimpulan: Tidak terdapat hubungan antara preeklampsia dan paritas terhadap kejadian partus prematurus.
\end{abstract}

Kata Kunci: Preeklampsia, Paritas, Partus Prematurus

\section{ABSTRACT}

Background: Preeclampsia is a condition in pregnant women who have hypertension with blood pressure $\geq 140 / 90$ $\mathrm{mmHg}$ that occurs after 20 weeks' gestation, and it's accompanied by proteinuria $\geq 300 \mathrm{mg} / 24$ hours. Every day in 2015,830 women die due to complications of pregnancy and childbirth including preeclampsia. Impaired maternal health such as preeclampsia will result in impaired fetal development. One of the development disorders of the fetus is preterm bith (premature birth). Premature births which affected by preeclampsia or eclamsia are caused by the spasm of blood vessels, if this goes long will disrupt the growth of the fetus and increase the tonus and the sensitivy of the uterus to stimulation so that cause the premature partus. Infants with premature conditions will experience disturbances in the future life such as asphyxia and neoatal death.

Aim: To determine the relationship between preeclampsia and parity with the incidence of premature partus.

Method: This research was observational analytic with cross-sectional mode. The sample was taken from preeclampsic patient's medical record at RSUD Banyumas of February until December 2017. The data was satistically analyzed with Chi-Square.

Results: Patients with primipara preeklampsia with premature labor as much as 48,3\%, patients with multipara preeclampsia with $29,0 \%$ premature labor and Chi- square test obtained $\mathrm{p}$ value $=0,721$.

Conclusion: There is no relationship between preeclampsia and parity to premature partus.

Keyword: Preeclampsia, Parity, Premature Partus 


\section{PENDAHULUAN}

Preeklampsia adalah keadaan pada ibu hamil dengan tekanan darah $\geq 140 / 90 \mathrm{mmHg}$ yang terjadi setelah umur kehamilan 20 minggu, dan disertai dengan proteinuria $\geq 300 \mathrm{mg} / 24 \mathrm{jam}^{1}$. Preeklampsia merupakan penyebab kematian ibu hamil kedua di dunia setelah perdarahan ${ }^{1}$. Data World Health Organization (WHO) tahun 2018, memperkirakan setiap harinya di tahun 2015, 830 perempuan meninggal karena terjadi komplikasi kehamilan dan persalinan termasuk preeklampsia. ${ }^{1}$

Preeklampsia di dunia memiliki angka kejadian berkisar $0,51 \%-38,4 \%$ dan di Indonesia preeklampsia memiliki frekuensi kejadian sekitar 3-10\%. Prevalensi preeklampsia di Jawa Tengah mengalami peningkatan sebesar 1,87\%, tahun 2009 sebesar 2,02\%, tahun 2010 sebesar 3,3\% dan pada tahun 2011 sebesar $3,41 \%^{2}$. Data terbaru menunjukan jumlah kasus kematian ibu di Provinsi Jawa Tengah pada tahun 2016 sebanyak 602 kasus, mengalami penurunan dibandingkan jumlah kasus kematian ibu tahun 2015 yang sebanyak 619 kasus $^{3}$.

Penelitian Ramadhayanti pada primigravida, preeklampsia dapat terjadi dengan prevalensi sekitar $85 \%$, sedangkan ibu multigravida mempunyai prevalensi preeklampsia sebesar $15 \%{ }^{4}$. Preeklampsia pada multigravida terjadi karena penurunan angiotensin, renin dan aldosteron sehingga dijumpai oedema, dan proteinuria. Kesehatan ibu yang terganggu seperti preeklampsia akan mengakibatkan gangguan pada perkembangan janin.

Kelahiran atau persalinan prematur merupakan persalinan yang terjadi pada usia kehamilan kurang dari 37 minggu (antara 20 sampai $<37$ minggu). Bayi dengan kondisi prematur akan mengalami gangguan dalam kehidupan selanjutnya seperti asfiksia dan kematian neonatal. Akhir-akhir ini, angka kematian bayi (AKB) sudah menjadi tolak ukur perbandingan sistem perawatan kesehatan internasional ${ }^{5}$

Kelahiran prematur di negara berkembang dapat disebabkan oleh infeksi genitourinaria, kehamilan ganda, pregnancy induced hypertension (PIH), Body Mass Index (BMI), inkompetensi serviks, riwayat melahirkan prematur, abruptio plasenta, pekerja berat dan merokok. Selain itu faktor risiko terjadinya kelahiran prematur adalah preeklampsia atau eklampsia, usia ibu $<20$ atau $>35$ tahun, jarak kehamilan dan bersalin terlalu dekat, paritas, status paritas, riwayat abortus, dan pendidikan $i b u^{6}$. 
Kelahiran prematur yang dipengaruhi oleh preeklampsia atau eklampsia diakibatkan oleh remodelling arteri spiralis uterina yang tidak sesuai pada awal kehamilan. Keadaan dengan perubahan decidua menyebabkan berkurangnya perfusi plasenta sehingga menyebabkan kelahiran premature ${ }^{7}$. Jika hipoksia berlangsung lama akan mengganggu pertumbuhan janin ${ }^{5}$.

\section{METODE}

Penelitian ini merupakan penelitian observasional analitik dengan rancangan penelitian crosssectional. Penelitian ini dilakukan di RSUD Banyumas mengambil data rekam medis pasien preeklampsia periode Januari sampai Desember 2017 yang memenuhi kriteria inklusi. Penelitian dilaksanakan pada bulan Januari sampai Maret 2018. Instrumen yang digunakan adalah data sekunder yang didapatkan dari rekam medis pasien. Pengumpulan data dimulai dari peneliti mengajukan ijin penelitian ke bagian Diklat RSUD Banyumas kemudian peneliti mendapatkan ijin penelitian dan diarahkan ke bagian rekam medis, selanjutnya peneliti mencatat data dari rekam medis yang dibutuhkan. Setelah data berhasil dikumpulkan, data diolah untuk mendapatkan hasil.

\section{HASIL}

Hasil analisis penelitian ini menunjukkan bahwa tidak terdapat hubungan pada pasien preeklampsia dan paritas dengan kejadian partus prematurus dengan nilai $\mathrm{p}=0,721$. Penelitian ini sesuai dengan penelitian Mutianingsih, menyatakan bahwa tidak ada hubungan antara preeklampsia berat dengan kelahiran preterm di ruang bersalin Rumah Sakit Umum Provinsi NTB periode 1 Juni - 29 Juli 2013 dimana nilai $p=0,610^{5}$. Data yang diperoleh kemudian dilakukan uji Chi-square untuk hubungan preeklampsia dan paritas dengan kejadian partus prematurus di RSUD Banyumas periode 1 Januari 2017 sampai 31 Desember 2017.

Pada penelitian ini menunjukkan tidak ada hubungan dikarenakan pengambilan sampel dilakukan di rumah sakit rujukan yang memiliki fasilitas lengkap/tenaga profesional yang cukup dalam menangani kasus preeklamsia berat sehingga komplikasi yang disebabkan oleh preeklamsi berat seperti kelahiran preterm dapat dicegah dan bisa dipertahankan sampai aterm.

\section{DISKUSI}

Pada penelitian ini menunjukkan tidak ada hubungan dikarenakan dalam satu rumah sakit rujukan (RSUD Banyumas) memiliki fasilitas lengkap/tenaga profesional yang cukup dalam menangani kasus 
preeklampsia berat sehingga komplikasi yang disebabkan oleh preeklampsi berat seperti kelahiran preterm dapat dicegah dan bisa dipertahankan sampai aterm.

Peran tenaga kesehatan dalam pelaksanaan $\mathrm{P} 4 \mathrm{~K}$ yaitu melakukan pendataan ibu hamil untuk mengetahui jumlah ibu hamil dan untuk merencanakan persalinan yang aman, persiapan menghadapi komplikasi dan tanda bahaya ke tenaga medis bagi ibu sehingga melahirkan bayi yang sehat danibu selamat dengan persalinan prematur berjumlah 40 pasien dan aterm berjumlah 84 pasien dari data rekam medis mengikutsertakan suami dan keluarga. Serta menggerakkan masyarakat dengan memberikan penyuluhan dan mengadakan pertemuan tiap bulan, mengikutsertakan masyarakat seperti: tokoh masyarakat, tokoh agama, kader dan dukun bayi ${ }^{8}$. Keikutsertaan masyarakat akan mempercepat terlaksananya program peningkatan mutu kesehatan dan tertanganinya resiko yang ada dengan cepat dan tepat dari hasil penelitian yang didapatkan maka perlu dilakukan pembahasan tentang faktor-faktor yang dapat mempengaruhi kejadian partus prematurus.

\section{KESIMPULAN}

1. Tidak terdapat hubungan antara preeklampsia dan paritas dengan kejadian partus prematurus.
2. Insidensi preeklampsia di RSUD Banyumas sejumlah 124 pasien dari data rekam medis.

3. Insidensi kasus preeklampsia dengan

\section{UCAPAN TERIMAKASIH}

Saya ucapkan terimakasih kepada keluarga besar dan civitas akademika Fakultas Kedokteran Universitas Muhammadiyah Purwokerto yang telah mendukung pembuatan artikel ini.

\section{REFERENSI}

1. Nugroho, Taufan. (2012).Patologi Kebidanan. Yogyakarta :Nuha Medika

2. Dinas Kesehatan Propinsi Jawa Tengah. (2017). Profil Kesehatan Provinsi Jawa Tengah Tahun 2016. Dinas Kesehatan Provinsi Jawa Tengah, 3511351(24), pp. 1-120.

3. Dinas Kesehatan Propinsi Jawa Tengah. (2012). Profil Kesehatan Jawa Tengah Edisi 4. Jakarta : EGC

4. Rahmadhayanti, E., Hayati, L.and Saleh, M. I. (2014). Hubungan Polimorfisme Gen Reseptor Angiotensin II Tipe 11166 A / C Dengan Kejadian Preeklampsia. Majalah Kedokteran Sriwijaya, 46(1), pp. 52-58. Available at: http://ejournal.unsri.ac.id/index.php/mks/article/ view/2682.

5. Mutianingsih, Rosa. (2014). Hubungan Preeklampsi Berat Dengan Kelahiran Preterm Di Rumah Sakit Umum Provinsi Nusa Tenggara Barat. Fakultas Ilmu Kesehatan, Universitas Nahdlatul Wathan Mataram :Media Bina Ilmiah. Volume 8, No. 3.

6. Eliza, R.\& Nuryani, D.D. (2017) Determinan Persalinan Prematur di RSUD Dr. Abdul Moeloek. Fakultas Kesehatan Masyarakat Universitas Malahayati. 05-309.

7. Rasmussen, S., Ebbing, C. and Irgens, L. M. (2017) 'Predicting preeclampsia from a history of preterm birth', PLoS ONE, 12(7), pp 1-10. doi: 10.1371/journal.pone.0181016. 
8. Rosmiati, tri anonim, S. (2016) 'Peran Bidan Dalam Pelaksanaan Program Perencanaan', 10, pp. 7079.

9. WHO. (2018). Maternal and Reproductive Health. Diakses dari :

http://www.who.int/gho/maternal_health/en/ Tanggal 18 Mei 2018

Lampiran.

Tabel 1. Distribusi Data Paritas dan Persalinan Prematur

\begin{tabular}{lll}
\hline Variabel & Jumlah & $p$ \\
\hline Primipara & & \\
Preterm & 6 & \\
Aterm & 26 & \\
Multipara & & 0,721 \\
Preterm & 36 & \\
Aterm & 56 & \\
& 124 & \\
\hline
\end{tabular}

